\title{
Choice experiment assessment of public expenditure preferences
}

\author{
Geoffrey N. Kerr, Ross Cullen, Kenneth F.D. Hughey \\ Lincoln University \\ New Zealand
}

\begin{abstract}
Preferences for changes to public expenditures were evaluated using a choice experiment. Results indicate potential efficiency gains from reallocation of expenditures to items with higher marginal welfare. In particular, respondents were found to prefer more spending on health, education and the environment, with health spending providing the highest marginal benefits. The public preferred less expenditure on income support. The choice experiment also identified the impacts of demographic factors. The approach is offered as a complement to prior approaches that research public preferences for budget allocation, with prospects for revelation of richer information for informing social decisions.
\end{abstract}

Key Words: Public expenditure preferences

JEL classification: H40, H50 


\section{Introduction}

Analysis of public preferences for government expenditures has taken a variety of forms. Research has addressed the scale of government spending (Gemmell et al., 2003; Preston \& Ridge, 1995), preferences for "redistribution" (Fong, 2001; Alesina \& La Ferrara, 2005; Alesina \& Giuliano, 2009), and whether expenditure on particular items should be More, the Same, or Less (MSL) than the existing allocation (e.g. Ferris, 1983; Lewis \& Jackson, 1985; Hills, 2002; Delaney \& O’Toole, 2007). Budget games provide another avenue for assessing public preferences. In these games people either reallocate expenditures without changing total spending (Bondonio \& Marchese, 1994), allocate surplus funds (Alvarez \& McCaffery, 2003; Blomquist et al., 2000, 2003; Israelsson \& Kriström, 2001) or cut portfolio budgets to meet a predetermined reduction in total spending (de Groot \& Pommer, 1987, 1989). Psychologists have used category rating and magnitude estimation approaches (Kemp, 2002).

The MSL approach is easy to apply, but provides relatively little information. MSL cannot identify the preferred scale of government expenditure, or the optimal allocation of spending between competing items. Budget games yield more information than MSL. Games with budget constraints can be useful for providing information about preferences for the distribution of small budget changes. Games in which the total budget is unrestricted can provide useful information about preferences for large budget changes, including optimal scale, but do not provide information on changes at the margin. Category rating and magnitude estimation can be useful for measuring total or marginal benefits (e.g. Kemp \& Willetts, 1995), although negative values cannot be measured, even though they are feasible and relevant to optimal allocations. Category rating can be used to rank benefits from alternative expenditure categories. However, unlike MSL and unconstrained budget games, the use of ratio measurement scales 
precludes estimates of marginal rates of substitution, which are required for optimally adjusting government expenditures.

The social welfare function is $\mathrm{W}\left(\mathrm{X}_{1}, \mathrm{X}_{2}, \ldots, \mathrm{X}_{\mathrm{n}}, \mathrm{Z}\right) . \mathrm{X}_{\mathrm{i}}$ is the amount of government funding allocated to portfolio $\mathrm{i}\left(\mathrm{X}_{\mathrm{i}} \geq 0\right)$ and $\mathrm{Z}$ is the total amount of tax money spent on these portfolios $\left(\mathrm{Z}=\Sigma_{\mathrm{i}} \mathrm{W}_{\mathrm{i}}\right)$. Additional spending on any portfolio has two effects. It changes welfare because of the outcomes from spending on the specific portfolio $\left(\delta \mathrm{W} / \delta \mathrm{X}_{\mathrm{i}}\right)$, the sign of which will be positive if additional spending is perceived to produce "goods", but is unknown a priori. The second effect arises from the source of the additional funds, which can come from two locations: increased taxes, which are expected to diminish community welfare directly $\left(\mathrm{dW}_{\mathrm{i}}=\mathrm{DZ} ; \delta \mathrm{W} / \delta \mathrm{Z}<0\right)$, reduction in spending in other portfolios $\left(\delta \mathrm{W} / \delta \mathrm{X}_{\mathrm{j}}, \mathrm{j} \neq \mathrm{i}\right)$, or some combination of the two. Optimal budget allocation involves maximising $\mathrm{W}$ subject to the constraints that (i) all $\mathrm{X}_{\mathrm{i}}$ are non-negative, and (ii) the total budget equals $\mathrm{Z}$, which can be fixed or variable. Trivially, the optimal first-order conditions for an internal solution (W must be twicedifferentiable) are $\delta \mathrm{W} / \delta \mathrm{X}_{\mathrm{i}}=\delta \mathrm{W} / \delta \mathrm{X}_{\mathrm{j}} \forall \mathrm{i}, \mathrm{j}$. In addition, when $\mathrm{Z}$ is a variable the optimal level of taxation requires $\delta \mathrm{W} / \delta \mathrm{X}_{\mathrm{i}}=-\delta \mathrm{W} / \delta \mathrm{Z} \forall \mathrm{i}$. Marginal welfare should be equated across portfolios and should offset the loss in welfare arising from appropriation of taxes.

\section{The study}

We explore a fresh approach towards providing information about preferences for government budget allocations. Choice experiments can inform government allocation decisions by deriving a welfare function, which can provide measures of (i) strength of preference for allocating marginal budget to specific portfolios, (ii) optimal total budget, 
and (iii) optimal allocation over portfolios.

Choice experiments are attribute based methods that present alternative products or policies that differ on a number of attributes. Experiment participants select their single preferred alternative, mimicking a political process. Each participant may make several choices between different sets of alternatives, which are designed to provide suitable data for application of random utility models to estimate the welfare function (Louviere et al., 2000; Bennett \& Blamey, 2001; Hensher et al., 2005).

A choice experiment was applied to test optimality of New Zealand budget allocation amongst four portfolios: health, education, income support (support), and conservation and environmental management (environment). Data were collected as part of a selfcompleted mail survey of registered voters that sought perceptions of the state of the New Zealand environment (Hughey et al., 2002). The response rate to the March 2002 survey was $45 \%(n=836)$.

Space limitations in the survey dictated a single extremely simple choice question (Figure 1). Nine choice sets, each comprised of three alternatives for spending on the four portfolios, were derived using an orthogonal design (Hahn \& Shapiro, 1966). The alternatives covered selected combinations of $\$ 50$ million more, the same, or $\$ 50$ million less annual spending on each of the portfolios. Options entailed total budget changes across the range of $\pm \$ 200$ million relative to the existing budget for these portfolios. The nine choice sets were evenly distributed across the survey sample so that each respondent was presented with only one choice set. Respondents identified the single alternative that they preferred from the three alternatives in the choice set presented to them. Figure 1 shows one of the choice sets. Information was provided on government 
spending on each of these items on the expectation that survey participants would be unaware of such matters (Kemp, 2009).

\section{Insert Figure 1 about here}

\section{Statistical methods}

Modelling assumed a linear welfare function, which is limited because it does not accommodate diminishing marginal welfare, which is necessary for an internal solution to the budget allocation problem. However, for small changes it is possible to approximate the welfare function using a linear form. Relative to the current budget, proposed changes were $0.4 \%$ (Support), 0.7\% (Education and Health), and 10\% (Environment). Further support of the linear utility function assumption is provided by Kemp and Willetts (1995), who found no significant difference in ratings for a 5\% increase or a $5 \%$ decrease in provision of specific New Zealand government services.

The underlying linear welfare function is:

$$
\mathrm{W} \quad=\beta_{1} \mathrm{X}_{1}+\beta_{2} \mathrm{X}_{2}+\beta_{3} \mathrm{X}_{3}+\beta_{4} \mathrm{X}_{4}+\beta_{5} \mathrm{Z}
$$

The total welfare effect of a purely tax-funded change in spending on portfolio $i$ is:

$$
\begin{aligned}
\mathrm{dW} / \mathrm{dX} & =\mathrm{d}\left(\beta_{1} \mathrm{dX}_{1}+\beta_{2} \mathrm{dX}_{2}+\beta_{3} \mathrm{dX}_{3}+\beta_{4} \mathrm{dX} \mathrm{X}_{4}+\beta_{5} \mathrm{dZ}\right) / \mathrm{dX} \\
& =\beta_{\mathrm{i}}+\beta_{5}
\end{aligned}
$$

Because $\mathrm{Z}$ is a linear function of the other parameters, it is not possible to identify (1). However, it is possible to identify (2): 
W

$$
=\alpha_{1} X_{1}+\alpha_{2} X_{2}+\alpha_{3} X_{3}+\alpha_{4} X_{4}
$$

Where $\quad \alpha_{\mathrm{i}}=\beta_{\mathrm{i}}+\beta_{5}=\mathrm{dW} / \mathrm{dX}$

$\alpha_{i}$ is net marginal welfare of spending on portfolio $i$, which includes the benefits obtained from spending on the portfolio, as well as the disutility of paying higher taxes to fund that additional spending. This is the model that was fitted to the data.

\section{Results}

Linear welfare functions estimated with multinomial logit models are reported in Table 1. Polynomial and logarithmic welfare functions were estimated, but provided no improvement over the simple linear model, which is unsurprising given the small scale of expenditure changes. Latent class and random parameters models failed to improve model fit.

\section{Insert Table 1 about here}

These models have only moderate predictive ability. However, the independent variables are all highly significant. The SUPPORT coefficients are negative, with asymptotic Zscores of -7.0 , indicating a definite preference for reduced spending on income support. The three other portfolio coefficients are all significantly positive, indicating preferences for increased spending on those items. Model B is preferred to Model A on all three statistical criteria in Table 1, a conclusion which is confirmed by a likelihood ratio test $\left(\chi^{2}=47.72,4\right.$ dof $)$. Unlike the other portfolios, marginal welfare from health spending did not differ significantly by age. 


\section{Policy analysis}

For efficiency, as judged by the public, whenever marginal welfare net of $\operatorname{tax}\left(\alpha_{i}\right)$ is positive taxes should be increased to allow additional spending on portfolio $i$ and vice versa. Additional taxes are justified to support increased spending on HEALTH, EDUCATION and ENVIRONMENT. On the other hand, efficiency is enhanced by reducing expenditure on SUPPORT in order to lower taxes. However, the linear utility function approximation precludes identification of optimal magnitudes of expenditure and tax changes.

Another possibility is reallocation of existing expenditures without change to the total tax take. Any increase of spending in one portfolio requires reductions in spending in at least one other portfolio. When spending on one item $\left(\mathrm{X}_{\mathrm{j}}\right)$ is reduced to allow increased spending on another $\left(\mathrm{X}_{\mathrm{i}}\right)$ with a balanced budget $\left(\mathrm{dX}_{\mathrm{j}}=-\mathrm{dX} \mathrm{X}_{\mathrm{i}}\right)$, the change in welfare is $\mathrm{dW}=\beta_{\mathrm{i}} \mathrm{dX}_{\mathrm{i}}+\beta_{\mathrm{j}} \mathrm{dX}$. Hence: $\mathrm{dW} / \mathrm{dX}_{\mathrm{i}}=\beta_{\mathrm{i}}-\beta_{\mathrm{j}}=\alpha_{\mathrm{i}}-\alpha_{\mathrm{j}}$. Efficiency is enhanced whenever expenditure is transferred from lower marginal welfare to higher marginal welfare portfolios. With a linear welfare function all spending should be transferred to the item with the largest marginal welfare net of tax $\left(\alpha_{i}\right)$. Table 2 provides estimates of differences in marginal welfares and their significance, estimated using a Monte Carlo procedure (Krinsky and Robb, 1986).

\section{Insert Table 2 about here}

The marginal welfare differences $\left(\beta_{\mathrm{i}}-\beta_{\mathrm{j}}\right)$ allow the items to be ranked. A positive difference indicates that marginal spending on portfolio i yields more welfare than spending on portfolio $\mathrm{j}$. Welfare would be improved by transferring spending from item $\mathrm{j}$ to item $\mathrm{i}$ in such cases. Two marginal welfare differences in Model B are not significantly different from zero, so Model B is unable to provide a full ranking of 
HEALTH, EDUCATION and ENVIRONMENT for the 50 year old in the example. HEALTH spending is significantly more valuable than ENVIRONMENT spending, but the differences between HEALTH and EDUCATION and between EDUCATION and ENVIRONMENT are unclear. Expenditure on any other portfolio provides more marginal welfare than spending on SUPPORT.

For Model A it is possible to conclude that HEALTH spending provides more benefits than either ENVIRONMENT or EDUCATION spending. The following hierarchy of marginal welfares applies with better than 95\% confidence: HEALTH $>$ \{EDUCATION, ENVIRONMENT $\}>0>$ SUPPORT.

Predictions from Model B vary significantly with respondent age (Table 3). Marginal welfares for HEALTH, EDUCATION and ENVIRONMENT are larger than for SUPPORT for all age groups, except for 70 year olds who no longer have a clear preference for ENVIRONMENT spending over SUPPORT. There are no significant differences in marginal welfare for ENVIRONMENT and EDUCATION for any age group. However, younger respondents were more likely to value ENVIRONMENT and EDUCATION spending more highly than HEALTH spending. This outcome is similar to results from category rating of New Zealand health budget preferences (Kemp \& Burt, 2001).

\section{Insert Table 3 about here}

\section{Discussion}

This preliminary study addressed budget allocations for a narrow range of government services and for small changes in portfolio expenditures. Results nevertheless indicated preferences for reduced spending on income support, a strong desire to spend more on health, and willingness to support additional spending on education and the 
environment, consistent with category rating studies. These results are consistent with other studies. The highest marginal value ratings in New Zealand category rating studies are achieved by health, education and police, with environment ranking in the middle range, and spending on income support always rated lowly (Kemp \& Willetts, 1995; Kemp, 1998, 2003; Kemp \& Burt, 2001).

Choice experiments allow application of mathematical models of preferences, which provides opportunities to statistically derive estimates of marginal utility, which are of value for estimating optimal budget allocations based on preferences - an advantage over other approaches. This suggests that further use of the approach on a broader range of services should be considered as well as including a broader range of demographic factors (Delaney and O'Toole, 2008a), as well as larger expenditure changes and designs suitable for estimating non-linear welfare functions. Results then could be compared directly with budget game outcomes. SUPPORT incorporates a large number of subcategories (e.g. pensions, unemployment benefit, single parent support) which may be judged quite differently (Lewis and Jackson, 1985; Delaney and O’Toole, 2008b). Disaggregation of SUPPORT may provide guidance about relative desirability of components of this portfolio.

The choice experiment approach to identification of efficient budget allocation is novel. This preliminary study has successfully estimated marginal welfare differences between portfolios within relatively narrow confidence intervals. There is potential to use choice experiments to identify marginal benefits as well as optimal budget allocations. This gives the choice experiment approach a theoretical advantage over category rating, budget games and MSL. This preliminary trial of the choice approach to modelling community preferences, along with the potential advantages the approach offers, indicates the method has strong potential and suggests that further research into design 
improvements is warranted. 


\section{References}

Alesina, A. \& Giuliano, P. (2009). Preferences for redistribution. NBER Working Paper 14825, National Bureau of Economic Research. Downloaded from http://www.nber.org/papers/w14825.

Alesina, A. \& La Ferrara, E. (2005). Preferences for redistribution in the land of opportunities. Journal of Public Economics, 89, 897-931.

Alvarez, R.M. \& McCaffery, E.J. (2003). Are there sex differences in fiscal political preferences? Political Research Quarterly, 56(1), 5-17.

Bennett, J. \& Blamey, R. (Eds) (2001). The choice modelling approach to environmental valuation. Cheltenham: Edward Elgar.

Blomquist, G. C., Newsome, M. A., \& Stone, D. B. (2000). Public marginal willingness to trade off among water quality programs: Estimates of statewide and watershed-specific budget values. Water Resources Research, 36(5), 1301-1313.

Blomquist, G. C., Newsome, M. A., \& Stone, D. B. (2003). Measuring principals' values for environmental budget management: an exploratory study. Journal of Environmental Management, 68, 83-93.

Bondonio, P. \& Marchese, C. (1994). Equilibrium in fiscal choices: Evidence from a budget game. Public Choice, 78(3-4), 205-218.

De Groot, H. \& Pommer, E. (1987). Budget-games and the private and social demand for mixed public goods. Public Choice, 52(3), 257-272.

De Groot, H. \& Pommer, E. (1989). The stability of stated preferences for public goods: Evidence from recent budget games. Public Choice, 60(2), 123-132.

Delaney, L. \& O’Toole, F. (2007). Decomposing demand for public expenditure in Ireland. Applied Economics Letters, 14, 1091-1095. 
Delaney, L. \& O’Toole, F. (2008a). Individual, household and gender preferences for social transfers. Journal of Economic Psychology, 29, 348-359.

Delaney, L. \& O’Toole, F. (2008b). Preferences for specific social welfare expenditures in Ireland. Applied Economics Letters, 15, 985-989.

Ferris, J.M. (1983). Demands for public spending: An attitudinal approach. Public Choice, 40, 135-154.

Fong, C. (2001). Social preferences, self-interest, and the demand for redistribution. Journal of Public Economics, 82, 225-246.

Gemmell, N., Morrissey, O. \& Pinar, A. (2003). Tax perceptions and the demand for public expenditure: evidence from UK micro-data. European Journal of Political Economy, 19, 793-816.

Hahn, G.J. \& Shapiro, S.S. (1966). A catalogue and computer programme for the design and analysis of symmetric and asymmetric fractional factorial experiments. New York: General Electric Research and Development Centre Report No. 66-0-165.

Hensher, D.A., Rose, J.M. \& Greene, W.H. (2005). Applied Choice analysis: a primer. Cambridge: Cambridge University Press.

Hills, J. (2002). Following or leading public opinion? Social security policy and public attitudes since 1997. Fiscal Studies, 23(4), 539-558.

Hughey, K.F.D., Kerr, G.N. \& Cullen, R. (2002). Perceptions of the state of the environment: the 2002 survey of public attitudes, preferences and perceptions of the New Zealand environment. Lincoln: Education Solutions.

Israelsson, T. \& Kriström, B. (2001). If I had 10 billion to spend: An empirical study of Swedes' preferences over budget allocation, in Israelsson, T. Infrastructure investments and environmental preservation: an economic foundation for public decisions. Umeå, Sweden: Department of Forest Economics, Swedish University of Agricultural Sciences, Report No. 122. 
Kemp, S. (1998). Rating the values of government and market supplied goods. Journal of Economic Psychology, 19, 447-461.

Kemp, S. (2002). Public Goods and Private Wants: A psychological approach to government spending. Cheltenham: Edward Elgar.

Kemp, S. (2003). The effect of providing misleading cost information on the perceived value of government services. Journal of Economic Psychology, 24, 117-128.

Kemp, S. (2009). Public perception of actual changes in New Zealand government spending. New Zealand Economic Papers, 43(1), 59-67.

Kemp, S. \& Burt, C.D.B. (2001). Estimation of the value and cost of government and market supplied goods. Public Choice, 107, 235-252.

Kemp, S. \& Willetts, K. (1995). Rating the value of government-funded services: Comparison of methods. Journal of Economic Psychology, 16, 1-21.

Krinsky, I. \& Robb, A.L. (1986). On approximating the statistical properties of elasticities. Review of Economics and Statistics, 68, 715-719.

Lewis, A. \& Jackson, D. (1985). Voting preferences and attitudes to public expenditure. Political Studies, 33, 457-466.

Louviere, J.J., Hensher, D.A., and Swait, J.D. (2000). Stated choice methods: analysis and application. Cambridge: Cambridge University Press.

Preston, I. \& Ridge, M. (1995). Demand for local public spending: evidence from the British Social Attitudes Survey. The Economic Journal, 105(430), 644-660. 
Table 1: Multinomial Logit Models

\begin{tabular}{|c|c|c|}
\hline & Model A & Model B \\
\hline HEALTH & $1.088 \mathrm{E}-2 * * *$ & $1.163 \mathrm{E}-2 * * *$ \\
\hline EDUCATION & $8.259 \mathrm{E}-3 * * *$ & $2.222 \mathrm{E}-2 * * *$ \\
\hline SUPPORT & $-6.996 \mathrm{E}-3 * * *$ & $-2.460 \mathrm{E}-2 * * *$ \\
\hline ENVIRONMENT & $6.859 \mathrm{E}-2 * * *$ & $2.137 \mathrm{E}-2 * * *$ \\
\hline AGE*EDUCATION & & $-2.635 \mathrm{E}-4 * * *$ \\
\hline AGE*SUPPORT & & 3.353 E- $4 * * *$ \\
\hline AGE*ENVIRONMENT & & $-2.782 \mathrm{E}-4 * * *$ \\
\hline Akaike Information Criterion & 1.873 & 1.810 \\
\hline Bayesian Information Criterion & 1.898 & 1.855 \\
\hline Adjusted $\rho^{2}$ & 0.093 & 0.126 \\
\hline
\end{tabular}

Significance levels ${ }^{*}(10 \%),{ }^{* *}(5 \%),{ }^{* * *}(1 \%)$ 
Table 2: Marginal utility differences

\begin{tabular}{llll}
\hline \multicolumn{1}{c}{$\mathrm{i}$} & $\mathrm{j}$ & \multicolumn{2}{c}{$\beta_{\mathrm{i}}-\beta_{\mathrm{j}}$} \\
\cline { 3 - 4 } & & Model A & Model B $^{*}$ \\
\hline HEALTH & EDUCATION & $0.0026^{* *}$ & $0.0025^{*}$ \\
HEALTH & ENVIRONMENT & $0.0040^{* * *}$ & $0.0041^{* * *}$ \\
EDUCATION & ENVIRONMENT & 0.0014 & 0.0016 \\
HEALTH & SUPPORT & $0.0179^{* * *}$ & $0.0194^{* * *}$ \\
EDUCATION & SUPPORT & $0.0153^{* * *}$ & $0.0170^{* * *}$ \\
ENVIRONMENT & SUPPORT & $0.0139^{* * *}$ & $0.0153^{* * *}$ \\
\hline
\end{tabular}

\# Differences are age-dependent. The marginal utility differences are for a 50 year old.

Significance levels ${ }^{*}(10 \%),{ }^{* *}(5 \%),{ }^{* * *}(1 \%)$ 
Table 3: Marginal utility differences, Model B

\begin{tabular}{|c|c|c|c|c|c|c|}
\hline \multirow[b]{3}{*}{ AGE } & HEALTH & HEALTH & EDUC & ENVIRON & HEALTH & EDUC \\
\hline & - & - & - & - & - & - \\
\hline & ENVIRON & EDUC & ENVIRON & SUPPORT & SUPPORT & SUPPORT \\
\hline 20 & $-0.0042^{*}$ & $-0.0053^{* *}$ & 0.0011 & $0.034^{* * *}$ & $0.030^{* * *}$ & $0.035^{* * *}$ \\
\hline 30 & -0.0014 & -0.0027 & 0.0013 & $0.028^{* * *}$ & $0.026^{* * *}$ & $0.029^{* * *}$ \\
\hline 40 & 0.0014 & 0.0000 & 0.0014 & $0.021^{* * *}$ & $0.023^{* * *}$ & $0.023^{* * *}$ \\
\hline 50 & $0.0041^{* * *}$ & $0.0026^{*}$ & 0.0016 & $0.015^{* * *}$ & $0.019^{* * *}$ & $0.017^{* * *}$ \\
\hline 60 & $0.0070^{* * *}$ & $0.0052^{* * *}$ & 0.0017 & $0.0092^{* * *}$ & $0.016^{* * *}$ & $0.011^{* * *}$ \\
\hline 70 & $0.0097^{* * *}$ & $0.0079^{* * *}$ & 0.0019 & 0.0030 & $0.013^{* * *}$ & $0.0049^{* *}$ \\
\hline
\end{tabular}

Significance levels ${ }^{*}(10 \%),{ }^{* *}(5 \%),{ }^{* * *}(1 \%)$ 
The New Zealand government spends about $\$ 36$ billion each year on a range of public services.

Suppose the government were thinking about changing the amount it spent on health, education, income support, and conservation and environmental management. Any increase in total spending on these items would result in a tax increase, but reduced spending could lower taxes. You are asked for your opinion on the following options. You might think there are better options than these ones, but they are the only options you can choose from for now. Which option do you prefer?

\begin{tabular}{|c|c|c|c|c|}
\hline \multirow[t]{2}{*}{ Area of public spending } & \multirow{2}{*}{$\begin{array}{l}\text { Approximate } \\
\text { amount spent } \\
\text { in } 2001 \\
\text { (\$ million) }\end{array}$} & \multicolumn{3}{|c|}{ Change in spending each year (\$ million) } \\
\hline & & Option 1 & Option 2 & Option 3 \\
\hline Health & $\$ 7,000 \mathrm{~m}$. & $\$ 50 \mathrm{~m}$. less & no change & $\$ 50 \mathrm{~m}$. more \\
\hline Education & $\$ 6,733 \mathrm{~m}$. & $\$ 50 \mathrm{~m}$. less & $\$ 50 \mathrm{~m}$. more & no change \\
\hline Income support & $\$ 13,000 \mathrm{~m}$. & $\$ 50 \mathrm{~m}$. less & $\$ 50 \mathrm{~m}$. more & no change \\
\hline $\begin{array}{l}\text { Conservation and } \\
\text { environmental management }\end{array}$ & $\$ 500 \mathrm{~m}$. & $\$ 50 \mathrm{~m}$. less & no change & $\$ 50 \mathrm{~m}$. more \\
\hline \multicolumn{2}{|l|}{ Change in total taxes collected } & $\$ 200 \mathrm{~m}$ less & $\$ 100 \mathrm{~m}$ more & $\$ 100 \mathrm{~m}$ more \\
\hline
\end{tabular}

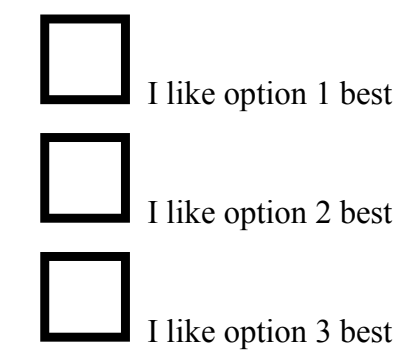

Figure 1: Example of a choice question 